\title{
The effect of dietary energy source on nitrogen metabolism in the rumen of sheep
}

\author{
BY N. W. OFFER*, R. F. E. AXFORD AND R. A. EVANS \\ Department of Biochemistry and Soil Science, \\ University College of North Wales, \\ Bangor, Gwynedd LL57 $2 U W$
}

\author{
(Received 27 February 1976 - Accepted 12 May 1976)
}

\begin{abstract}
I. Seven isonitrogenous diets were prepared containing soya-bean meal and dried grass either unsupplemented, or supplemented with wheat starch or paper or equal mixtures of both.

2. The diets were allocated according to a balanced incomplete block design to seven Clun Forest wether sheep, each fitted with a re-entrant duodenal cannula.

3. After each sheep had received a diet for $6 \mathrm{~d}$, daily samples of digesta were collected automatically for the next $3 \mathrm{~d}$.

4. The amounts of dry matter, gross energy and major nitrogenous components consumed in the diet, passing into the duodenum and excreted in the urine and faeces were determined.

5. A novel method was applied to estimate the proportion of the total amino acids passing into the duodenum which was of microbial origin.

6. The amounts of microbial total amino acids synthesized were compared with the amounts of energy disappearing in the rumen for each of the seven diets tested. For the starch- and paper-containing diets an average of $14.7 \mathrm{~g}$ microbial total amino acid passed into the duodenum per MJ energy disappearing in the rumen, whilst for the diets containing either paper or starch alone the mean value, $6 \cdot \mathrm{I} g / \mathrm{MJ}$, was significantly lower $(P<0.05)$.

7. The results of the experiment suggested that the energy released from a mixture of starch and paper was utilized more efficiently for microbial protein synthesis than when the energy was provided by supplements of either paper or starch alone.
\end{abstract}

Hogan \& Weston (1970) studied the relationship between the passage of nitrogenous materials to the duodenum and the nitrogen:digestible organic matter in the diet of sheep given ad lib. a number of pasture plants which differed widely in nutritive value. They concluded that protein synthesis in the rumen was frequently limited by the amount of biologically-useful energy that the rumen micro-organisms could obtain from the diets.

In the present study, the basis for this conclusion was broadened by studying the effect of different energy sources on the flow of nitrogenous materials to the duodenum, using semipurified diets differing only in carbohydrate content. A preliminary experiment carried out on a single sheep has been reported previously (Offer, Evans \& Axford, $1972 b$ ). A short report of the present study has been given by Offer, Evans \& Axford (I975).

\section{EXPERIMENTAL}

\section{Sheep and diets}

Seven adult Clun Forest wether sheep, each previously fitted with a re-entrant cannula in the proximal duodenum, were housed in metabolism cages and were fed automatically at $2 \mathrm{~h}$ intervals. Water was available to the sheep at all times. A basal diet was compounded, providing (g/d): soya-bean meal 250 , milled dried grass 150 , mineral-vitamin mixture (ICI Cattle and Sheep; ICI Ltd, Alderley Park, Macclesfield) 30, molasses 80, chromic oxide 2.

\footnotetext{
* Present address: West of Scotland College of Agriculture, Auchincruive, Ayr KA6 sHW.
} 


\section{N. W. Offer, R. F. E. Axford and R. A. Evans}

This basal diet was supplemented with $(\mathrm{g} / \mathrm{d}) 300$ or 600 wheat starch or paper or equal quantities of each (diets $300 \mathrm{~S}, 600 \mathrm{~S}, 300 \mathrm{P}, 600 \mathrm{P}, 150 \mathrm{SP}$ and $300 \mathrm{SP}$ respectively). The diets were pelleted before feeding.

\section{Experimental design}

The seven diets were fed to the seven sheep according to a balanced incomplete block design, in which each treatment was replicated three times. Each sheep received a diet for a period of $9 \mathrm{~d}$. On the sixth day of each period, the re-entrant cannula was linked to an automatic device (Axford, Evans \& Offer, 197I) collecting representative samples, which were a constant proportion of the digesta passing to the duodenum. Daily samples were taken for the next $4 \mathrm{~d}$, freeze-dried and stored for subsequent analysis. Urine (preserved by acidification) and faeces were also collected. The daily dietary intake was recorded and any uneaten food was removed.

\section{Chemical analysis}

Analyses were carried out on bulk $3 \mathrm{~d}$ samples. Dry matter was determined by drying to constant weight at $105^{\circ}$. Gross energy (GE) was measured using a ballistic bomb calorimeter (Miller \& Payne, 1959). Ammonia was determined by the method of Fawcett \& Scott (I960), adapted to the AutoAnalyser (Technicon Instrument Co. Ltd, Basingstoke RG2 I2YE, Hants). Samples for total $\mathrm{N}$ determination were digested on a semi-micro scale using the reagents of Siriwardine, Thomas, Evans \& Axford (1966) and analysed using the AutoAnalyser. Total amino acids were measured by hydrolysis with $6 \mathrm{M}$-hydrochloric acid at $108^{\circ}$ for $24 \mathrm{~h}$ under an atmosphere of $\mathrm{N}_{2}$, followed by automated ion-exchange chromatography (Thomas, 1970). $\mathrm{Cr}_{2} \mathrm{O}_{3}$ was determined by a modification of the method of Stevenson \& Clare (I 963 ). Urinary allantoin was measured by a modification of the method of Pentz (1969).

\section{RESULTS}

The diets were designed to provide a $\mathrm{N}$ intake of $65 \mathrm{~g} / 3 \mathrm{~d}$. Soya-bean meal provided $85.3 \%$ and dried grass $14.7 \%$ of this amount. Table $\mathrm{I}$ gives the measured total $\mathrm{N}$ intakes and also the allocation of sheep to the seven diets. In four of the twenty-one experimental periods there were significant food refusals. All three sheep given diet $600 \mathrm{P}$ refused approximately $40 \%$ of the food provided. Sheep no. 6 also refused a large quantity of diet 300 SP. In order to allow for these differences in intake all digesta, urine and faeces values were normalized to a standard $\mathrm{N}$ intake of $65 \mathrm{~g} / 3 \mathrm{~d}$, assuming a direct proportionality between intake and the measurement made.

Table 2 gives the corrected treatment mean values for the recovery of dietary $\mathrm{Cr}_{2} \mathrm{O}_{3}$ at the duodenum and faeces. Over the whole experiment, the recovery of $\mathrm{Cr}_{2} \mathrm{O}_{3}$ was (mean $\pm \mathrm{SE}$ ) $98.0 \pm 3.0 \%$ at the duodenum and $93.0 \pm 2.6 \%$ in the faeces. The recoveries in digesta samples for diet $300 \mathrm{SP}$ and in faecal samples for diet $300 \mathrm{P}$ differed significantly $(P<0.05)$ from $100 \%$. On the evidence of previous experiments (Offer, Evans \& Axford, 1972a), we are satisfied that $\mathrm{Cr}_{2} \mathrm{O}_{3}$ used as described, is an accurate marker for dry matter in digesta passing to the duodenum. In the present experiment, all flow values were corrected to give $100 \%$ recovery of the administered dose. Faecal values were similarly corrected.

The results were analysed statistically by standard methods for balanced incomplete blocks (Yates, 1936) to obtain treatment means free from variation due to differences between sheep.

The results for the digestion of dry matter and GE are given in Table 3. The over-all digestibilities were lowest for diets $300 \mathrm{P}, 600 \mathrm{P}$ and $300 \mathrm{SP}$. The digestibilities of diets $300 \mathrm{P}$ and $300 \mathrm{SP}$ were significantly $(P<0.05)$ lower than those of the other diets except $600 \mathrm{P}$. It 
Table I. Intake of dietary total nitrogen $(\mathrm{g} / 3 d)$ by sheep given diets differing in carbohydrate content

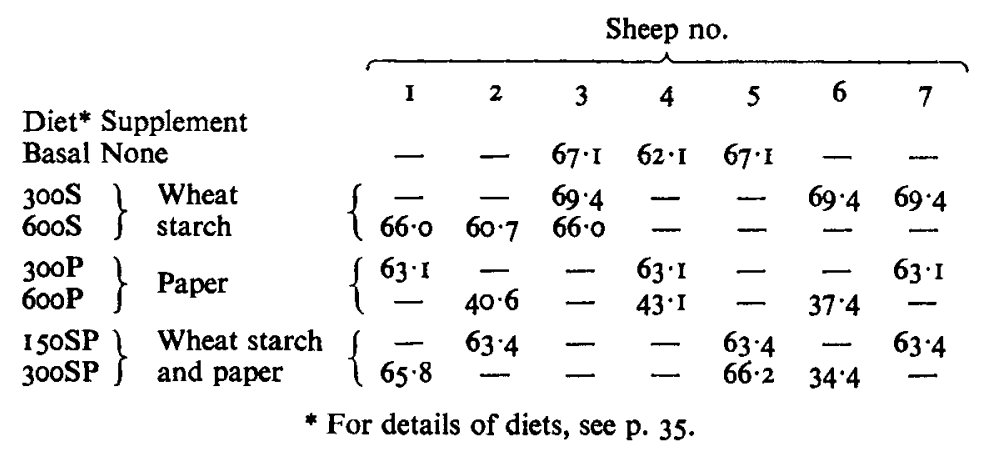

Table 2. Recovery (\%) of dietary chromic oxide in digesta and faeces from sheep given diets differing in carbohydrate content

(Mean values for three determinations/dietary treatment)

\begin{tabular}{|c|c|c|c|}
\hline Diet* & Supplement & Duodenal digesta & Faeces \\
\hline Basal & None & $96 \cdot 7$ & $90 \cdot 3$ \\
\hline $\begin{array}{l}300 S \\
600 S\end{array}$ & Wheat starch & $\left\{\begin{array}{l}103 \cdot 2 \\
111 \cdot 4\end{array}\right.$ & $\begin{array}{l}95 \cdot I \\
91 \cdot 3\end{array}$ \\
\hline $\left.\begin{array}{l}300 P \\
600 P\end{array}\right\}$ & Paper & $\begin{array}{l}98 \cdot 5 \\
94 \cdot 3\end{array}$ & $\begin{array}{l}85 \cdot 2 \\
94 \cdot 6\end{array}$ \\
\hline $\left.\begin{array}{l}\begin{array}{l}\text { I50SP } \\
\text { 300SP }\end{array}\end{array}\right\}$ & Wheat starch and paper & $\left\{\begin{array}{l}98 \cdot 5 \\
83 \cdot 4\end{array}\right.$ & $\begin{array}{r}102 \cdot 4 \\
92 \cdot 3\end{array}$ \\
\hline SE of means & * For detail & $7 \cdot 2$ & $6 \cdot 3$ \\
\hline
\end{tabular}

Table 3. Amounts of dietary dry matter $(\mathrm{g} / 3 d)$ and gross energy $(M J / 3 d)$ digested by sheep given diets differing in carbohydrate content

(Mean values for three determinations/dietary treatment, adjusted to a standard intake of $65 \mathrm{~g}$ total nitrogen $/ 3 \mathrm{~d}$ )

\begin{tabular}{|c|c|c|c|c|c|c|c|c|c|}
\hline \multirow[b]{2}{*}{ Diet* } & \multirow[b]{2}{*}{ Supplement } & \multicolumn{4}{|c|}{ Dry matter } & \multicolumn{4}{|c|}{ Gross energy } \\
\hline & & Intake & $\begin{array}{l}\text { Flow to } \\
\text { duodenum }\end{array}$ & Faeces & $\begin{array}{c}\text { Apparent } \\
\text { digestibility }\end{array}$ & Intake & $\begin{array}{l}\text { Flow to } \\
\text { duodenum }\end{array}$ & Faeces & $\begin{array}{c}\text { Apparent } \\
\text { digestibility }\end{array}$ \\
\hline Basal & None & 1310 & 755 & 286 & 0.768 & $22 \cdot 3$ & $10 \cdot 0$ & $4 \cdot 2$ & 0.796 \\
\hline $\left.\begin{array}{l}300 S \\
600 S\end{array}\right\}$ & $\begin{array}{l}\text { Wheat } \\
\text { starch }\end{array}$ & $\begin{array}{l}2032 \\
2769\end{array}$ & $\begin{array}{r}775 \\
1454\end{array}$ & $\begin{array}{l}426 \\
616\end{array}$ & $\begin{array}{l}0.794 \\
0.773\end{array}$ & $\begin{array}{l}35 \cdot 3 \\
48 \cdot 0\end{array}$ & $\begin{array}{l}11 \cdot 8 \\
22 \cdot 1\end{array}$ & $\begin{array}{r}7 \cdot 2 \\
I I \cdot I\end{array}$ & $\begin{array}{l}0.798 \\
0.765\end{array}$ \\
\hline $\begin{array}{l}300 P \\
600 P\end{array}$ & Paper & $\begin{array}{l}2242 \\
2830\end{array}$ & $\begin{array}{l}1446 \\
1472\end{array}$ & $\begin{array}{l}913 \\
949\end{array}$ & $\begin{array}{l}0.589 \\
0.662\end{array}$ & $\begin{array}{l}39 \cdot 3 \\
48 \cdot 2\end{array}$ & $\begin{array}{l}20 \cdot 1 \\
22 \cdot 9\end{array}$ & $\begin{array}{l}15 \cdot 6 \\
17.4\end{array}$ & $\begin{array}{l}0.600 \\
0.636\end{array}$ \\
\hline $\left.\begin{array}{c}150 \mathrm{SP} \\
300 \mathrm{SP}\end{array}\right\}$ & $\begin{array}{l}\text { Wheat } \\
\text { starch and } \\
\text { paper }\end{array}$ & $\left\{\begin{array}{l}2236 \\
2815\end{array}\right.$ & $\begin{array}{l}1740 \\
2263\end{array}$ & $\begin{array}{r}679 \\
\text { II } 17\end{array}$ & $\begin{array}{l}0.700 \\
0.605\end{array}$ & $\begin{array}{l}40 \cdot 0 \\
47 \cdot 5\end{array}$ & $\begin{array}{l}26 \cdot 3 \\
32 \cdot 5\end{array}$ & $\begin{array}{l}11 \cdot 6 \\
20 \cdot 2\end{array}$ & $\begin{array}{l}0.715 \\
0.573\end{array}$ \\
\hline SE of me & & 一 & 100 & 85 & 0.034 & - & $1 \cdot 8$ & $1 \cdot 6$ & 0.037 \\
\hline
\end{tabular}




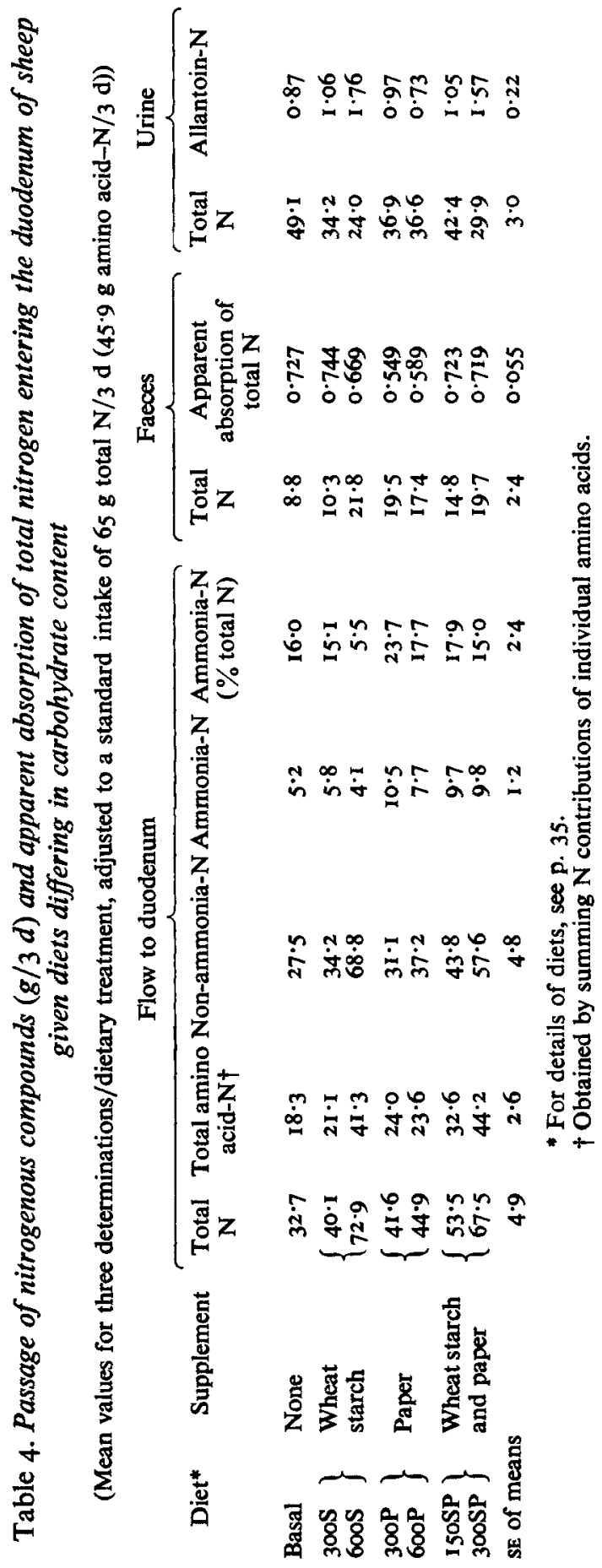




\section{Dietary energy source and $N$ metabolism}

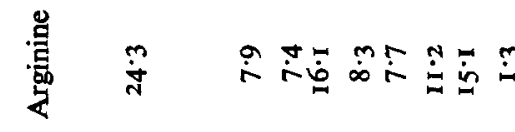

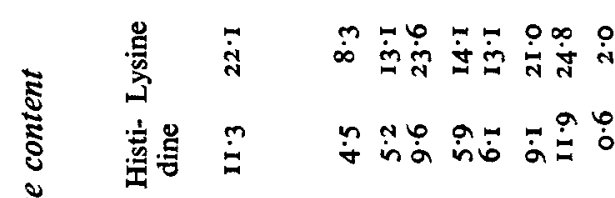

ชั

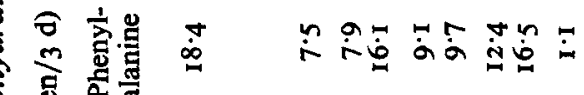

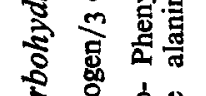

:

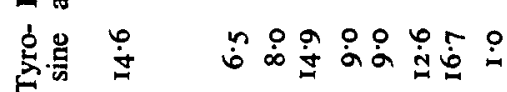

$\$$

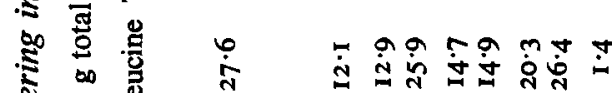

象

突

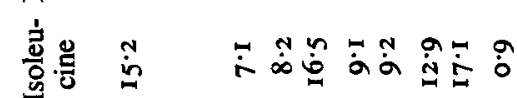

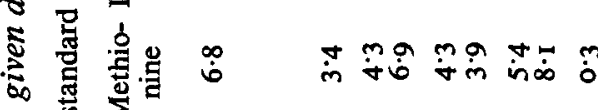

華

政

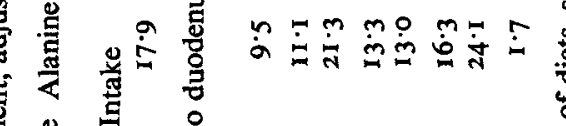
要

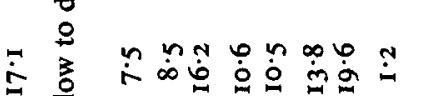

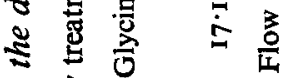

2 实

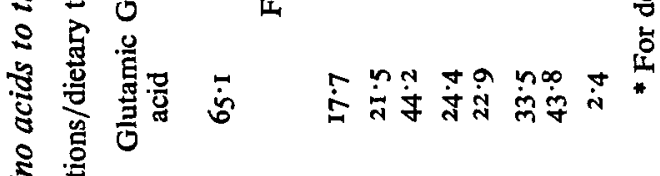

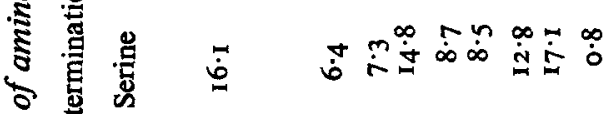

है

劳

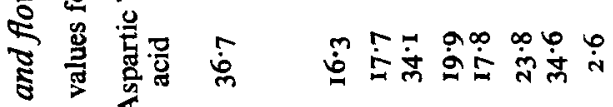

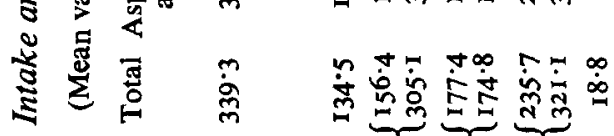

in

苗

0
0
0
0
0

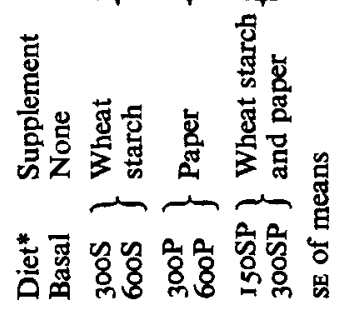


Table 7. Estimated contribution of microbial, dietary and endogenous amino acids $(\mathrm{g} / 3 d)$ to the total amino acids in the duodenal digesta of sheep given diets differing in carbohydrate content

(Mean values for three determinations/dietary treatment, adjusted to a standard intake of $65 \mathrm{~g}$ total nitrogen $/ 3 \mathrm{~d}$ )

\begin{tabular}{|c|c|c|c|c|}
\hline Diet* & Supplement & $\begin{array}{l}\text { Microbial amino } \\
\text { acids }\end{array}$ & $\begin{array}{l}\text { Dietary amino } \\
\text { acids }\end{array}$ & $\begin{array}{l}\text { Endogenous amino } \\
\text { acids }\end{array}$ \\
\hline Basal & None & $86 \cdot 9$ & $3 I \cdot 3$ & $13 \cdot 8$ \\
\hline $\left.\begin{array}{l}300 S \\
600 S\end{array}\right\}$ & Wheat starch & $\left\{\begin{array}{l}120 \cdot 3 \\
192 \cdot 5\end{array}\right.$ & $\begin{array}{l}30 \cdot 4 \\
97 \cdot 6\end{array}$ & $\begin{array}{r}3 \cdot 1 \\
11 \cdot 8\end{array}$ \\
\hline $\left.\begin{array}{l}300 P \\
600 P\end{array}\right\}$ & Paper & $\left\{\begin{array}{l}133.5 \\
125 \cdot 2\end{array}\right.$ & $\begin{array}{l}33 \cdot 8 \\
3 I \cdot 7\end{array}$ & $\begin{array}{r}7 \cdot 3 \\
13 \cdot 0\end{array}$ \\
\hline $\left.\begin{array}{l}\begin{array}{l}150 S P \\
300 S P\end{array}\end{array}\right\}$ & Wheat starch and paper & $\left\{\begin{array}{l}163 \cdot 8 \\
221 \cdot 3\end{array}\right.$ & $\begin{array}{l}56 \cdot 6 \\
68 \cdot 8\end{array}$ & $\begin{array}{r}9 \cdot 6 \\
23 \cdot 4\end{array}$ \\
\hline SE of means & & $25 \cdot 2$ & $9 \cdot 6$ & $5 \cdot 2$ \\
\hline
\end{tabular}

should be noted that the value obtained for diet $600 \mathrm{P}$ was likely to be an over-estimate because of the correction applied to allow for the low intake of this diet.

Table 4 give values for the passage of nitrogenous compounds. There was a significant $(P<0.05)$ loss of total $\mathrm{N}$ between the mouth and the duodenum for the basal diet and diets $300 \mathrm{~S}, 300 \mathrm{P}$ and $600 \mathrm{P}$. The mean flows of total $\mathrm{N}$ at the duodenum were higher than the total $\mathrm{N}$ intakes for diets $600 \mathrm{~S}$ and $300 \mathrm{SP}$ although these differences were not significant. Carbohydrate supplementation of the basal diet resulted in increased flows of non-ammonia- $\mathbf{N}$ and total amino acid-N to the duodenum. These increases were significant $(P<0.05)$ for diets $600 \mathrm{~S}, 150 \mathrm{SP}$ and $300 \mathrm{SP}$. The flow of total amino acid-N for diet I 50SP was significantly higher than for diets $300 \mathrm{~S}$ or $300 \mathrm{P}$. The flows of non-ammonia-N and total amino acid-N for diet $600 \mathrm{P}$ were significantly lower than those obtained for diets $600 \mathrm{~S}$ and $300 \mathrm{SP}$.

The flow of ammonia- $\mathrm{N}$ to the duodenum was lowest for the basal diet and diets $300 \mathrm{~S}$ and $600 \mathrm{~S}$. When expressed as a percentage of total $\mathrm{N}$ passing to the duodenum there was no significant difference between treatments except with diet $600 \mathrm{~S}$. The total $\mathrm{N}$ in the digesta flowing to the duodenum for diet $600 \mathrm{~S}$ contained a much lower proportion of ammonia-N.

There were no significant differences in total $\mathrm{N}$ excreted in the faeces for diets $600 \mathrm{~S}, 300 \mathrm{P}$, $600 \mathrm{P}$ and $300 \mathrm{SP}$, but each was significantly $(P<0.05)$ higher than the level for the basal diet. The apparent absorption of total $\mathrm{N}$ passing to the duodenum was lowest for diets $300 \mathrm{P}$ and $600 \mathrm{P}$ (basal diet supplemented with paper). On average, $67 \%$ of the total $\mathrm{N}$ entering the intestine disappeared.

Supplementation of the basal diet with carbohydrate reduced the amounts of total $\mathrm{N}$ excreted in the urine. The lowest values were obtained for diets $600 \mathrm{~S}$ and $300 \mathrm{SP}$. The amount of allantoin- $\mathrm{N}$ excreted in the urine was increased by carbohydrate supplementation except for diet $600 \mathrm{P}$. The values obtained for diets $600 \mathrm{~S}$ and $300 \mathrm{SP}$ were significantly $(P<0.05)$ higher than for the basal diet.

Table 5 gives the intake and duodenal flow of amino acids. For each amino acid there was a large loss between the mouth and the duodenum when the basal diet was fed. Carbohydrate supplementation led to increased flow of amino acids. The highest flows were obtained for diets $600 \mathrm{~S}$ and $300 \mathrm{SP}$. The flows of methionine and histidine were significantly $(P<0.05)$ higher for diet $300 \mathrm{SP}$ than for diet $600 \mathrm{~S}$. For diet $300 \mathrm{SP}$ significantly $(P<0.05)$ more alanine and methionine passed to the duodenum than was consumed. 


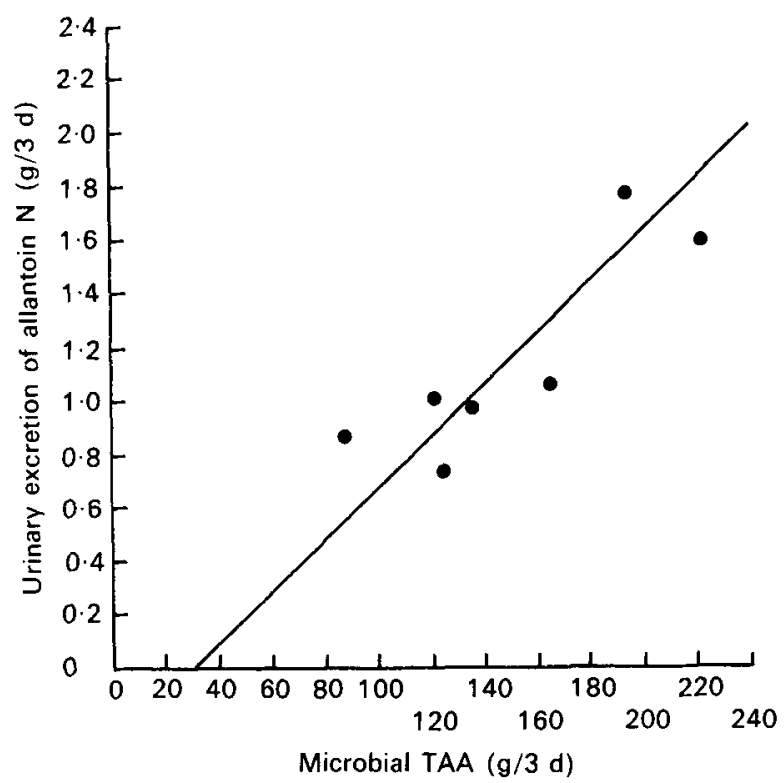

Fig. I. Relationships between urinary allantoin $N$ excretion $(g / 3 \mathrm{~d})$ and the estimated microbial total amino acid (TAA) flow $(\mathrm{g} / 3 \mathrm{~d})$ at the duodenum in sheep given diets differing in carbohydrate content (for details of diets, see p. 35). $r 0.84 ; Y=30.2( \pm 27.2)+103.8( \pm 29.5) X$, where $X$ is urinary allantoin $\mathrm{N}$ excretion, and $Y$ is microbial TAA flow.

\section{DISCUSSION}

\section{Estimation of microbial protein passing to the duodenum}

The proportion and amount of duodenal total amino acids present as microbial protein was estimated using the method of Evans, Axford \& Offer (1975). This method depends on the generation, by computer, of an amino acid profile by mixing in different proportions the known profiles of dietary, bacterial and endogenous constituents which are expected at the duodenum. The profiles used for bacterial and endogenous constituents are listed in Table 6 . The best match of this to the composition of the duodenal digesta is obtained by an iterative process, which continues until the sum of squares of residuals is minimal. The computer program finds the proportion of total amino acids attributable to each constituent which minimizes the objective function:

$$
\Sigma \text { (digesta actual-digesta calculated) }{ }^{2} \text {. }
$$

The program carries out an organized search for the lowest value of this function. Constraints are applied by adding a penalty to the function whenever the search enters a forbidden zone. These zones exist because no dietary constituent of the digesta is permitted to exceed the intake of that constituent nor may any constituent be negative.

Table 7 gives the results of application of this method to the values obtained in the present experiment. On average, $69 \%$ of the flow of total amino acids at the duodenum was attributed to microbial protein. This value agrees closely with our calculated values for the soya-bean-meal-starch-cellulose diets studied by Goshtasbpour-Parsi, Ely, Boling, Alderson \& Amos (1974). Application of the optimization method to the amino acid values given by these authors gave values of 69 and $67 \%$ microbial protein in the digesta for diets which contained $\mathrm{I} 50$ and $3 \mathrm{IO} \mathrm{g}$ soya-bean meal $/ \mathrm{kg}$ respectively as the only protein source.

In the present experiment only small amounts of soya-bean-meal protein escaped degrada- 
Table 8. The energetic efficiency of microbial total amino acid production in sheep given diets differing in carbohydrate content

(Mean values for three determinations/dietary treatment, adjusted to a standard intake of $65 \mathrm{~g}$ total nitrogen $/ 3 \mathrm{~d}$ )

\begin{tabular}{|c|c|c|c|c|}
\hline \multirow[t]{2}{*}{ Diet* } & \multirow[t]{2}{*}{ Supplement } & \multicolumn{2}{|c|}{$\begin{array}{l}\text { Energy disappearing before the } \\
\text { duodenum }\end{array}$} & \multirow{2}{*}{$\begin{array}{l}\text { Microbial total } \\
\text { amino acids: energy } \\
\text { disappearing } \\
(\mathrm{g} / \mathrm{MJ})\end{array}$} \\
\hline & & $\mathrm{MJ} / 3 \mathrm{~d}$ & Gross energy intake $(\%)$ & \\
\hline Basal & None & $12 \cdot 2$ & 55.9 & $7 \cdot 6$ \\
\hline $\left.\begin{array}{l}300 S \\
600 S\end{array}\right\}$ & Wheat starch & $\left\{\begin{array}{l}23.5 \\
25.9\end{array}\right.$ & $\begin{array}{l}67 \cdot 0 \\
55 \cdot 5\end{array}$ & $\begin{array}{l}5 \cdot 8 \\
6 \cdot 8\end{array}$ \\
\hline $\left.\begin{array}{l}300 P \\
600 P\end{array}\right\}$ & Paper & $\left\{\begin{array}{l}19 \cdot 2 \\
25 \cdot 3\end{array}\right.$ & $\begin{array}{l}47 \cdot 9 \\
49 \cdot 9\end{array}$ & $\begin{array}{l}7 \cdot 7 \\
4 \cdot 4\end{array}$ \\
\hline $\left.\begin{array}{l}\begin{array}{l}150 S P \\
300 S P\end{array}\end{array}\right\}$ & Wheat starch and paper & $\left\{\begin{array}{l}13 \cdot 7 \\
15 \cdot 0\end{array}\right.$ & $\begin{array}{l}34 \cdot 9 \\
30 \cdot 7\end{array}$ & $\begin{array}{l}13 \cdot 0 \\
15 \cdot 7\end{array}$ \\
\hline SE of means & & $1 \cdot 8$ & $4 \cdot I$ & $2 \cdot 9$ \\
\hline
\end{tabular}

tion in the rumen. The amount of total amino acids passing to the duodenum attributable to the soya-bean meal was significantly greater $(P<0.05)$ than zero for diets $600 \mathrm{~S}$ and I $50 \mathrm{SP}$ only.

Although there were no significant differences between diets in the amounts $(\%)$ of total amino acids passing to the duodenum identified as microbial amino acids, no relationship was found between microbial and dietary or endogenous amino acid flow. There were, however, large differences in the total passage of microbial amino acids to the duodenum. Supplementation of the basal diet with $300 \mathrm{~g}$ each of paper and starch/d resulted in an increase in microbial total amino acids passing to the duodenum from 87 to $22 \mathrm{Ig} / 3 \mathrm{~d}$. The duodenal flow of microbial amino acids for diets $600 \mathrm{~S}, 150 \mathrm{SP}$ and $300 \mathrm{SP}$ was significantly greater $(P<0.05)$ than for the basal ration.

Results shown in Fig. I suggest that the excretion of allantoin in urine is related to the microbial protein synthesis in the rumen. Although allantoin arises from the catabolism of purines derived from microbial, dietary, and endogenous nucleic acids, there is a significant relationship $(P<0.02)$ between microbial amino acids passing to the duodenum and the excretion of allantoin in the urine. The large standard errors of the coefficients of the regression equation limit its use for predictive purposes.

\section{Effect of energy source on amino acids passing to the duodenum}

A comparison of the efficiency with which each carbohydrate source was utilized for microbial protein synthesis was made by calculating the amounts of microbial total amino acids passing to the duodenum per MJ food energy disappearing between the mouth and the duodenum.

The values of energy disappearing before the duodenum expressed as $\mathrm{MJ} / 3 \mathrm{~d}$ and as a percentage of the GE intake are given in Table 8. When expressed as a percentage of GE intake, the highest value was that for the $300 \mathrm{~S}$ diet, the values for the basal diet and for diets $600 \mathrm{~S}, 300 \mathrm{P}$ and $600 \mathrm{P}$ were lower and the lowest values were those for diets $150 \mathrm{SP}$ and $300 S P$. These groups were distinguishable at $P<0.05$. These values for preduodenal digestibility, when compared with those for over-all digestibility of energy previously described (Table 3), indicated a shift in the relative importance of different sites of digestion for the various diets. It should be remembered, however, that both the preduodenal and over-all 
digestibilities for diet $600 \mathrm{P}$ may have been over-estimated due to the correction applied for the low intake of this diet.

Table 8 also gives the amounts of microbial total amino acids passing to the duodenum per MJ energy apparently disappearing between the mouth and the duodenum. The values for diets $150 S P$ and $300 S P$ (mean $14.4 \mathrm{~g} / \mathrm{MJ}$ ) were significantly higher $(P<0.05)$ than those for the other diets (mean $6 \cdot 3 \mathrm{~g} / \mathrm{MJ}$ ).

The results of the present experiment suggested that the energy released from a mixture of starch and paper in the rumen was utilized more efficiently for microbial protein synthesis than when the energy was provided in supplements of either starch or paper alone. This may account for the synergistic effect of dietary constituents in promoting the flow of $\mathrm{N}$ to the duodenum reported by Offer et al. (1972b) and Chamberlain \& Thomas (1974).

Values for microbial total amino acids:energy disappearing between the mouth and the duodenum for diets containing both starch and paper were similar to those which can be calculated from values reported for mixed and forage diets assuming that I kg apparently digested organic matter is equivalent to I8 MJ. The calculated values ( $\mathrm{g}$ microbial protein synthesis/MJ organic matter apparently digested in the rumen) range from 3.7 to $7 \cdot 3$ (Liebholtz, 1972; Liebholtz \& Hartmann, 1972), 17.5 to $21 \cdot 3$ (Lindsay \& Hogan, 1972) and a value of 12.8 (Hogan \& Weston, 1970). Liebholtz (1972) concluded that the efficiency of microbial protein synthesis in the rumen depends on protein source. This response probably depends on the ability of the different dietary proteins to maintain optimal ammonia concentrations in the rumen for microbial growth since we have found that supplementing a diet of chopped hay $(670 \mathrm{~g} / \mathrm{kg})$ and milled barley $(330 \mathrm{~g} / \mathrm{kg})$ with urea or ammonium acetate or ammonium lactate leads to increased energetic efficiency of microbial protein synthesis (Offer, Evans \& Axford, 1976). The results of the present experiment suggest that the nature of the energy source also has a considerable effect.

This work was carried out while N.W.O. was in receipt of a Rank Poctdoctoral Fellowship. We are grateful to the Lord Rank Research Centre for feed components.

\section{REFERENCES}

Axford, R. F. E., Evans, R. A. \& Offer, N. W. (1971). Res. vet. Sci. 12, 28.

Bergen, W. G., Purser, D. B. \& Cline, J. H. (1968a). J. Anim. Sci. 27, 1497.

Bergen, W. G., Purser, D. B. \& Cline, J. H. (1968 b). J. Dairy Sci. 51, 1698.

Burris, W. R., Bradley, N. W. \& Boling, J. A. (1974). J. Anim. Sci. 38, 200.

Chamberlain, D. G. \& Thomas, P. C. (1974). Proc. Nutr. Soc. 33, 59A.

Chow, R. B. \& Kassell, B. (1968). J. biol. Chem. 243, 1718.

Evans, R. A., Axford, R. F. E. \& Offer, N. W. (1975). Proc. Nutr. Soc. 34, 65A.

Fawcett, J. K. \& Scott, J. E. (1960). J. clin. Path. 13, 156.

Goshtasbpour-Parsi, B. G., Ely, D. G., Boling, J. A., Alderson, N. E. \& Amos, H. E., (1974). J. Anim. Sci. 39,643 .

Hogan, J. P. \& Weston, R. H. (1970). In Physiology of Digestion and Metabolism in the Ruminant, p. 474

[A. T. Phillipson, editor]. Newcastle-upon-Tyne: Oriel Press.

Hoeller, H. \& Harmeyer, T. (1964). Z. Vet. Med. Reike, A 3, 244.

Hoogenraad, N. J. \& Hird, F. J. R. (1970). Br. J. Nutr. 24, 119.

Ibrahim, E. A. \& Ingalls, J. R. (1972). J. Dairy Sci. 55, 971.

Liebholtz, J. (1972). Aust. J. agric. Res. 23, 1073.

Liebholtz, J. \& Hartmann, P. E. (1972). Aust. J. agric. Res. 23, 1059.

Lindsay, J. R. \& Hogan, J. P. (1972). Aust. J. agric. Res. 23, 321.

Meyer, R. H., Bartley, E. E., Deyoe, C. W. \& Colenbrander, V. F. (1967). J. Diary Sci. 50, 1327.

Miller, D. S. \& Payne, P. R. (1959). Br. J. Nutr. 13, 50 I.

Offer, N. W., Evans, R. A. \& Axford, R. F. E. (1972a). Proc. Nutr. Soc. 31, 41 A.

Offer, N. W., Evans, R. A. \& Axford, R. F. E. (1972 b). Proc. Nutr. Soc. 3I, I04A.

Offer, N. W., Evans, R. A. \& Axford, R. F. E. (1975). Proc. Nutr. Soc. 34, 67 A.

Offer, N. W., Evans, R. A. \& Axford, R. F. E. (I976). J. agric. Sci., Camb. 87, 567. 
44 N. W. Offer, R. F. E. Axford and R. A. Evans

Oltjen, R. R., Slyter, L. L., Williams, E. E. \& Kern, D. L. (197I). J. Nutr. ror, IOI.

Pentz, E. I. (1969). Adv. Automated Analysis I, I I .

Purser, D. B. \& Buechler, S. M. (1966). J. Dairy Sci. 49, 8 I.

Sharma, H. R. \& Ingalls, J. R. (1974). Can. J. Anim. Sci. 54, 157.

Siriwardine, J. A. de S., Thomas, A. J., Evans, R. A. \& Axford, R. F. E. (1966). J. Sci. Fd. Agric. 17, 456.

Stevenson, A. E. \& Clare, N. T. (1963). N.Z. Jl. agric. Res. 6, 121.

Thomas, A. J. (1970). Automation, Mechanisation and Data Handling in Microbiology, p. I07; London: Academic Press.

Weller, R. A. (1957). Aust. J. biol. Sci. 10, 384.

Williams, P. P. \& Dinusson, W. E. (1973). J. Anim. Sci. 36, 15 I.

Yates, F. (1936). Ann. Eugen. 7, I 2 I. 